\title{
Macroamylase Measurement
}

National Cancer Institute

\section{Source}

National Cancer Institute. Macroamylase Measurement. NCI Thesaurus. Code C111243.

A measurement of macroamylase present in a sample. 